\title{
A CONCISE HISTORY OF THE GREEK CATHOLIC CHURCH IN SLOVAKIA FOLLOWING THE FALL OF THE COMMUNIST REGIME HISTORICAL AND SOCIAL EXCURSUS IN THE YEARS $1989-2002$
}

The purpose of this paper is to present a concise historical and wider societal development of the Greek Catholic Church in Slovakia, or more precisely in Czechoslovakia, in the years 1989 - 2002. The Velvet revolution of 1989 triggered a collapse of the totalitarian regime in Czechoslovakia, bringing positive changes for the Greek Catholic Church, too. 40 years of the Greek Catholic Church persecution in Slovakia had come to an end and the Church could finally seize the opportunity to fully rehabilitate and develop their activities in all spheres of life. In the years 1989 - 2002, the Church was led by the seventh Greek Catholic Bishop of Presov Mons. Jan Hirka, during which time numerous renewal processes started to take effect in the Church's life.

Keywords: History, Greek Catholic Church in Slovakia, Jan Hirka, Slovakia in the years 1989 - 2002.

\section{Introduction: The Dawn of a New Era}

The very first positive and largely significant event for the Greek Catholic Church in Czechoslovakia after the fall of the communist regime [1] was the filling of an empty episcopal seat in Presov that been vacant since the death of Bishop Pavol Peter Gojdic in 1960. On 21 December 1989, one month after the events of November 17, the then Ordinary of the Greek Catholic Church, Mons. Jan Hirka, was appointed the seventh residential Bishop of Presov with an authority over the whole territory of Czechoslovakia (1989 - 2002) [2]. On February 17, 1990, Mons. Hirka received his episcopal consecration from His Eminence Mons. Jozef Cardinal Tomka, the Prefect of the Congregation for the Evangelization of Peoples. The other two co-consecrators were Bishop Michal Rusnak from Toronto and Bishop Slavomír Miklovs from the Croatian Eparchy of Krizevec. The ceremonial episcopal chirotonia (consecration) took place in the Town Sport Hall in Presov in the presence of bishops from all over the world, regional priests and the believers. Two archbishops and eleven bishops represented the Greek Catholic Church. Two Roman Catholic cardinals, one archbishop and five bishops from abroad were also present. Czechoslovak Episcopacy was represented by two archbishops and eight bishops [3]. The ceremonial enthronization of the new residential Greek Catholic Bishop
Hirka was held at the Cathedral of St. John the Baptist in Presov on the following day, on Sunday, February 18, 1990 [4].

\section{Bishop Hirka's Demands on Behalf of the Greek Catholic Church}

Shortly after being appointed to his office, Jan Hirka had to face many challenges. The major challenge was to accomplish a full rehabilitation of the Greek Catholic Church. The most important task proved to be the return of the Greek Catholic episcopal residence (in the nation-wide restitution of property), numerous parish churches and the the Church's seminary and theological faculty. On December 12, 1989, prior to his appointment as a bishop, Jan Hirka formulated the demands of the Greek Catholic Church from the state published in the magazine Slovo. The demands were as follows:

- "To declare the so called Sobor of 1950 null and void according to both ecclesiastical and state laws,

- to annul cadastral records based on the Ordinance No. 20285/51II-I issued on February 13, 1952 by the former State Bureau for Church Affairs and to declare the Ordinance null and void,

- to make a cadastral transfer of the cathedral and the bishop's residence, together with the adjacent buildings, namely the

\footnotetext{
* Jaroslav Coranic

Department of Historical Sciences, Greek-Catholic Theological Faculty, University of Presov in Presov, Slovakia

E-mail: jaroslav.coranic@unipo.sk
} 
library, the archive and the shop Petra, to the Greek Catholic Church,

- to surrender the building of a former Greek Catholic orphanage and present-day Faculty of Orthodox Theology and establish the Faculty of Greek Catholic Theological and Priest Seminary there,

- to rehabilitate the late Bishop Pavol Gojdic and all those who were convicted,

- to re-establish district deans in Kosice and Stara Lubovna (V. Skorodensky, or J. Soltys),

- to surrender the Greek Catholic monastic churches in Michalovce and Stropkov,

- to surrender monastic houses of male and female orders and restore them to the conditions before 1950,

- to permit monastic orders and a free (church) press,

- to obtain planning permission to build churches and parish buildings "where necessary",

- to surrender a parish building in Kosice and to establish a parish building in Bratislava,

- to close the deposit accounts for the sold church properties and pay them out to the Greek Catholic ecclesial community and to return the money that had been obtained,

- to agree with the demands of other Churches in the Czechoslovak Socialist Republic, namely to repeal the Act on state supervision over Churches and giving state consent to execution of pastoral activities,

- to create conditions for church activities in areas involving building churches, education, formation and studies of seminarians, lay associations and access to mass media" [5].

Since 1990, the Greek Catholic Church has managed to retrieve its residence in Presov and almost all of its churches and parish buildings. Although these buildings were returned in rather poor condition, the enthusiasm, effort and devotion of the people and the clergy led by the Ordinary Jan Hirka greatly contributed to the reconstruction of all churches and parish buildings.

\section{The Tedious Process of Reclaiming and Renewing the Church's Property}

\section{The Bishop's Residence}

The return of the bishop's residence was a result of a process involving handing over the church properties from the Orthodox Christians to the Greek Catholics agreed upon by the representatives of the Slovak government, the Eastern Slovak Regional National Committee (KNV) in Kosice, the District National Committee (ONV) in Presov and the representatives of both Churches involved. The act of returning the bishop's residence to the hands of the Greek Catholics was rather "interesting". It began on April 10, 1990. The representatives of the Orthodox Church surrendered the residence to the Committee of State Administration led by the head of the
Municipal National Committee (MsNV) in Presov PhDr. Ivan Benko. Late that day the Committee handed over the residence to the representatives of the Greek Catholic Church, namely to the Bishop's Office director PhDr. Pavol Dancak and the archivist Eugen Kocis [6]. Jan Chovanec, who was an editor of the independent weekly magazine Slobodny piatok, visited representatives of both Churches as well as Dr. Ivan Benko, the head of the Municipal National Committee (MsNV) and very realistically captured the atmosphere of those days as well as the whole process. In his article entitled Disputes are bad medicine. On matters troubling believers of two Churches in one region (Nezhody sú zlý liek. O otázkach, ktoré trápia veriacich dvoch cirkví v jednom kraji) he introduced an interreligious situation in East Slovakia half year after the Velvet revolution. Jan Chovanec commented on this process: "The Greek Catholics had been without their property for forty years. No wonder they started to claim it back right away, in the first days of the Velvet revolution. But who would abandon what had been entrusted to them four decades ago without demur? And so, at first the date to surrender the residence kept being postponed until the intermediary - a committee headed by the head of the Municipal National Committee Ivan Benko was created [7]." The Orthodox did not want to surrender this property, claiming that they had received it from the state and it is, therefore, the state only that must resolve this situation. Nikolaj, the Archbishop of Presov, the then highest representative of the Orthodox Church, refused the participation in the state-led transfer of the property from the Greek Catholics to the Orthodox. He commented on this matter as follows:

I was not yet a clergyman at that time but I know that we were not involved in the liquidation of the Greek Catholic Church. We were not pleased with what was happening then, but it was beyond our control. Nobody asked us whether we want it or not. Even their property was imposed upon us. Could the Roman Catholic Church have refused Pacem in terris? No. And neither could we have said that all was going to be as we wanted. They would have dealt with such daring people at once. Two of our metropolitans Jelevferij and Ján took early retirement for they did not agree with the state administration. The position was assumed by another metropolitan and he did as he was asked [7].

The Orthodox Church left the bishop's residence in a very poor condition. All rooms were empty for all the furniture had been taken away. All that was left were doorframes and door sills. The electrical installation and power distribution were destroyed, so were all sanitary facilities [7]. All power switches and light fittings were also removed. A valuable crystal chandelier lay on the floor in one of the rooms. When the editor of Slobodny piatok asked the Orthodox Archbishop to take his stand on this situation he replied: "I came to the eparchy in 1965, so I cannot tell you where all the original possession is. The possession we took away belonged to us. Apart from that all that I removed was the Italian water faucet I had bought myself. One of our people took a boiler because it was his. One sink got broken. But the doors, doorsills, 
switches and light fittings were all there when I left the eparchy at 2 PM." When asked about the chandelier, Imrich Belejkanič a director of Eparchial Council said: "Our people were carrying away that big chandelier, but when we were told by the appointed person that the chandelier was theirs I ordered our people to return it." The editor asked himself what had happened between 14:00 and 20:00 when the residence was officially taken over from the Committee of the MsNV by theGreek Catholic representatives. He further continued in his own reasoning, posing a rhetorical question: "which new building (note of an author: a new building of the Orthodox Bishop's Office) would this chandelier be a good match for? Why bother dismantling it and damaging the fragile parts of a precious chandelier? ...People leaving this place perhaps did not even realize they were leaving something that did not belong to them People coming back had tears in their eyes realizing that something was being returned back to them" [7].

The Bishop's residence was not liveable in such condition. A complex reconstruction needed to be carried out. Specialist work was done by a construction company from Presov with the assistance of volunteers from the congregation of believers. The reconstruction process was completed mainly due to a financial support from several foreign foundations. The state contributed only partially [8].

\section{The Faculty and Seminary Building}

Even more intricate seemed the situation surrounding the Faculty and the Seminary. The Municipal National Committee in Presov started the process of dispossession of a building belonging to the Seminary and the Theological Academy, in favour of the town of Presov, as early as December 1949. However, the premises were still used for teaching and living purposes of the Greek Catholic seminarians until April 1950. In the following years, the building passed through the hands of several owners. For instance, it was owned by the national enterprise Krizik, Masokombinat (Meat processing plant) in Presov and the Czechoslovak Bus Company in Presov [9]. For some time, after its relocation from Prague, the original building of the Greek Catholic Seminary was a seat of the Faculty of Orthodox Theology [10]. The Faculty of Orthodox Theology was then moved again, to the building of the former Greek Catholic orphanage in Presov. The original historical building of the Seminary passed to the Directorate of Restauracie a jedálne (Restaurants and Diners) and in 1961 to the Faculty of Arts of the UPJS in Kosice with a seat in Presov [9 and 11]. At the beginning of the 1970s, the MsNV in Presov decided that it was "necessary" to erect a new building for the Jonsa Zaborsky Theatre. Based on that decision, the building of the Greek Catholic Seminary and Academy was demolished during the second half of the year 1973 and a first half of the year 1974. The construction works on the site of a new theatre commenced in June 1974.

On May 3, 1990, the Federal Assembly of the Czech and Slovak Federal Republic passed the Act No. 163 on Theological Faculties. In accordance with this Act, the Faculty of the Greek Catholic Theology was established (Art 1, § 1, sec. 4) and, at the same time, incorporated into the University of Pavol Jozef Safarik v Kosice (The University of Pavol Jozef Safarik comprised three faculties: Faculty of Medicine, Faculty of Natural Science, Faculty of Law /all three in Kosice/ and Faculty of Arts, Faculty of Pedagogy, The Greek Catholic Theological Faculty and the Orthodox Theological Faculty /all four in Presov/) [12]. Since the original building of the Theological Academy and the Priest Seminary had already been demolished, the Greek Catholic Church wanted to locate these institutions in the building of former orphanage, which was still used by the Orthodox Church. Therefore, the Greek Catholic Church demanded its swift return. However, that was not finalized until August 10, 1990.

The MsNV in Presov was trying to find a suitable object for the Faculty of the Orthodox Theology and Seminary and that caused some delays in the whole process. Some suitable objects were eventually found but they were still occupied by several Romany families. That was the reason for yet another delay since the town had to find some alternative accommodation for those families, too [7].

\section{The Beginning of a New Theological Training}

Doc. Vladimír Polacek was appointed the first dean of the Faculty of Greek Catholic Theology after its restoration and Vasil Kormanik was appointed the first rector of the Seminary. 43 seminarians were to be transferred to Presov from Bratislava where they had studied at the Faculty of Roman Catholic Theology of Cyril and Methodius [13]. However, the building of the Faculty and Seminary was returned in dire condition that required at least basic reconstruction. The new academic year could not commence on time since the necessary reconstruction works had to be carried out. Vasil Kormanik, the rector of the Seminary, assumed responsibility and reconstruction began with a substantial help of the seminarians. The Municipal Building Office in Presov carried out some specialized construction works [14].

The official opening of the academic year 1990/1991 was held on November 3, 1990 and was preceded by the holy liturgy at the Cathedral of St. John the Baptist in the presence of the Bishop of Presov Jan Hirka, the Apostolic Nuncio in the Czech and Slovak Federal Republic Giovanni Coppa, the Bishop of Kosice Alojz Tkac and the rector of Pavol Jozef Safarik University in Kosice prof. Rudolf Korec [13, p. 8].

Initially, the teaching was carried out in the premises of present-day Greek Catholic Seminary (former Greek Catholic orphanage). During the first academic year, the study was made accessible to lay men and women (as the first theological faculty in the territory of former Czechoslovakia; the theological faculties in Prague and Olomouc introduced this option in later years) [15]. 
The Faculty offered only one study programme - General Catholic Theology with the enrollment of 82 students in the first academic year [16]. In the second academic year, the Great Chancellor - the residential bishop Jan Hirka - provided the Faculty with additional premises in the Bishop's Palace. In that year, there were 141 students [17]. One year later, in the academic year 1992/1993 the faculty had 272 students [18], so the Bishop Hirka decided to provide additional rooms in another part of the Bishop's Palace which were until 1989 occupied by the Faculty of Pedagogy of Pavol Jozef Safarik University [19]. In the same academic year, the Dean's Office and all administrative, technical and economic departments of the faculty were moved to the same building. These premises have been a home to the Greek Catholic Theological Faculty of Presov University in Presov since.

The building of the new faculty was in urgent need of reconstruction which was finally carried out in 1993 - 1994 with a financial support of foreign sponsors mainly from Switzerland and Germany, since the financial contribution from the state towards the reconstruction of the (state) faculty was minimal [20]. This reconstruction provided new lecture and administrative rooms, hence allowing admission of more students. Five years after the reconstruction, in the academic year 1995/1996, the faculty had 550 students (130 seminarians and 420 lay students) in the study programme of the General Catholic Theology Teaching of Religion and Ethics [21]. After the Faculty had moved, the building of the former Greek Catholic orphanage became fully available to the Greek Catholic Priest Seminary. As numbers of seminarians grew, the building no longer met the requirements of a modern seminary. For this reason, it was necessary to divide seminarians into two buildings. Some seminarians were accommodated on the premises of Bishop's Palace and the Faculty of the Greek Catholic Theology and the others in the orphanage building. A general reconstruction of the Seminary started in 1994 and it was completed on the $21^{\text {st }}$ of November 1996 when the ceremonial consecration took place in the presence of the former Slovak president Michal Kovac. The Seminary bears the name of Blessed Bishop Pavol Peter Gojdic [22].

\section{The Theological Faculty Becomes a Part of the University of Presov}

On December 10, 1996, the National Council of the Slovak Republic passed the Act No. 361 on division of Pavol Jozef Safarik University in Kosice. Effective as of January 1, 1997, the University of Presov with a seat in Presov came into existence. The Greek Catholic Faculty was subsequently incorporated in the University of Presov. Similarly, the Greek Catholic Seminary became a special purpose facility of the newly established University of Presov [23]. In 2005 the Faculty of Greek Catholic Theology changed its name to the Greek Catholic Theological Faculty. The new name better expressed the mission of the faculty which is to provide education in the field of theology not only to candidates for priesthood (seminarians) but also to lay students [24]. The Greek Catholic Theological Faculty in Presov largely contributed to an increase of priests in the Greek Catholic Church after 1989. In 13 years of his bishop's service, Jan Hirka ordained 165 priests [25].

Some nurseries, elementary as well as secondary schools started to operate in the Presov Greek Catholic Eparchy after 1989. During the episcopacy of Ján Hirka several schools were established: St. George Elementary in Svidnik (September 1, 1992), the Church Nursery of Sister Josaphata in Lutina (September 1, 1999, founded by the Congregation of Sisters Servants of the Immaculate Virgin Mary), Secondary Medical School of St. Basil the Great in Presov (September 1, 1990, founded by the Congregation of Sisters of St. Basil the Great) and the Grammar School of St. John Chrysostom in Humenne (September 1, 1998).

\section{The Story of the Church Archive}

Also located in the building of the Greek Catholic Bishop's Office was the Bishop's Archive. After 1950, the Bishop's Archive, like all other Greek Catholic institutions, was transferred under the jurisdiction and later ownership of the Orthodox Church.

In 1956, after the agreement between the state and the church institutions had come into effect, the state authorities took over the administration of the Archive. As of March 31, 1956, the Regional Administration of the Ministry of Inferior Affairs in Presov took over the Archive of the former Greek Catholic eparchy and a part of the Seminary Archive (the Seminary had its own archive) [26]. The Archive was under the administration of the state during the years 1956 - 1993, during which time its resources were incorporated into the State District Archive in Presov. The archival materials of the ecclesiastical archive were stored in the original building of the former Presov Greek Catholic Bishop's Palace until the end of the 1950s. At the beginning of the 1960s, the archive was gradually moved to the building of the State District Archive in Presov (district of Nizna Sebastova). In 1993, the resources of the Greek Catholic Bishop's Archive were excluded from the State District Archive and then returned to the Greek Catholic Church [27].

\section{The Appointments of Church Dignitaries Following the Year 1992}

The Presov Greek Catholic Eparchy extended over the whole territory of Czechoslovakia. Its administration over such a vast territory brought about many difficulties. For that reason, the Holy See appointed Mons. Milan Chautur, CSsR (the then viceprovincial of the Congregation of the Most Holy Redeemer in 
Slovakia) an auxiliary bishop. He assumed his office on January 11, 1992.

At the age of 34, a titular bishop of Cresima, Mons Milan Chautur became the youngest Catholic bishop in Czechoslovakia. On February 29, 1992, Milan Chautur received his episcopal consecration from the residential Bishop of Presov Mons. Jan Hirka. The co-consecrators were Bishop Michal Rusnak, CSsR from the St. Cyril and Methodius Eparchy in Toronto and the then Apostolic Nuncio in the Czech and Slovak Federal Republic titular bishop of Serta Mons. Giovanni Coppa [28]. The episcopal consecration was again held in the Town Sport Hall in Presov and was attended by many clergy and believers. On the following Sunday, March 1, 1992, Mons. Michal Chautur was initiated into his office in the Church of Father's Redemptorists in Michalovce. Mons. Milan Chautur worked in Presov for almost five years, assisting the residential bishop Ján Hirka in his pastoral ministry to the believers [29].

\section{The Papal Visit of $\mathbf{1 9 9 5}$ and the Beatification Processes}

The greatest event in the history of the Presov Greek Catholic Eparchy was the papal visit of John Paul II on July 2, 1995. John Paul II arrived to Presov from Kosice and his first stop was at the Cathedral of St. John the Baptist just before 5 PM. He first prayed there in front of the open royal doors of iconostasis. Then, in the company of the Bishop of Presov Mons. Jan Hirka, the Pope John Paul II entered the Chapel of St. Peter and Paul and prayed at the tomb containing the remains of now beatified Bishop Pavol Peter Gojdic, OSBM. The highlight of the papal visit to Presov was his meeting with around 200.000 believers who, together with the Pope, prayed Akathist to the Most Holy Lady Mother of God. In his address to the gathered crowd, John Paul II recognized the heroism of the Greek Catholic Church, emphasizing its value, beauty and profoundness. He stressed that the presence of the Greek Catholic Church is a telling testimony of how to be, despite all difficulties, faithful to an original model created by Cyril and Methodius. He spoke of a model created in order to combine diversity of traditions with the need of unity that Christ wanted for his Church. In his address, the Holy Father compared the communities of Eastern Rite Catholics to the small Tatra lakes - tarns [30].

The episcopacy of Jan Hirka was marked by several very important events. First, the beatification process of Bishop Pavol Peter Gojdic OSBM was successfully completed and secondly, the beatification process of Bishop ThDr. Vasil Hopko continued without interruption. The process of beatification of Bishops of Presov Pavol Peter Gojdic and Vasil Hopko and the Bishop of Mukachevo, Teodor Romza, had already started in the Greek Catholic Archeparchy of Pittsburgh, USA in 1986. On May 27, 1986, the Congregation for the Causes of the Saints sent a decree to Mons. Stefan Kocisko (the then Greek Catholic Archbishop in Pittsburgh). The Congregation approved the preparation of beatification processes of bishops Teodor Romza, Pavol Peter Gojdic and Vasil Hopko in Pittsburgh archeparchy, USA. However, the cause could not be officially opened due to the totalitarian regime in Czechoslovakia. Many important sources and materials needed for the process, as well as the most witnesses were in the country [31].

Eight years later, on 17 December 1994, the Congregation for the Causes of Saints granted Nihil obstat to the case of Pavol Peter Gojdic and Vasil Hopko [32]. It was the Pope John Paul II who indirectly gave an impulse to continuation, or initiation of the beatification processes at the level of Presov Greek Catholic Eparchy. During his official visit to Presov in 1995 he said:

We all remember the dramatic situation in the recent past, when the powers of ideology which are so contrary to human freedom and dignity condemned your religious community to extinction. God, however, removed the mighty from the throne and elevated those who had been humiliated (Luke 1, 52) for they were sympathetic to each other in their love for Christ...The Greek Catholic Church community came out of this trial renewed and strengthened also thanks to the testimony and the blood of many martyrs. The faith of a large number of lay persons, monks, nuns, priests and spiritual pastors is a living testimony of that. Just remember the suffering of Bishop Vasil Hopko and the martyrdom of Bishop Pavol Gojdic. On the brink of the third millennium it is a valuable contribution that your community brings in favour of ecumenism [33].

The Pope remembered the martyrdom of Bishops Pavol Peter Gojdic, OSBM and Jan Vojtassak again during his homily in Marianska Hora in Levoca when he said the following: "Both were imprisoned on the basis of pseudo-trials. Today they deserve the beatification process because they gave a great testimony to a loyal service of Church in Slovakia" [34].

On October 19, 1995, the Secretary of the Congregation for the Causes of Saints Archbishop Edward Nowak addressed a decree to Bishop of Presov Jan Hirka informing him that the Greek Catholic Eparchy in Presov should continue in the cause of beatification of bishops P. Gojdic and V. Hopko. The decree stated: "since the political situation in Slovakia has changed, the preparation of beatification process must take place in the diocese where Bishops Gojdic and Hopko had died, that is in the Eparchy of Presov. It should be done in accordance with the Canon Law and as requested by His Excellency Metropolitan - Archbishop of the Byzantine Catholic Church Judson Michael Procyk, successor to His Exc. Archbishop Stefan Kocisko" [31, p. 78].

The diocesan (eparchial) stage of the beatification process of Father Bishop Pavol Gojdic, OSMB was officially initiated in the Chapel of the Bishop's residence in Presov on 17 July 1998, the $110^{\text {th }}$ anniversary of his birth [35]. The diocesan stage of the beatification process of Father Bishop Vasil Hopko was initiated on January 30, 2001. There were three commissions appointed to prepare the diocesan stage of the beatification process: the Law 
Commission, the Commission of Experts in Historical Matters and in Matters that pertain to Archives, and the Commission of Theological Censors. The diocesan stages were successfully completed on March 24, 2001 when the final meetings took place. The Congregation for the Causes of Saints verified both causes and confirmed the legal validity of the diocesan stages in April 2001 [36]. The stage in which Roman Congregation of Rites decides was opened for both causes on May 4, 2001. After an examination and an affirmative vote of the Congregation for the Causes of Saints, the Pope John Paul II issued two decrees, one on September 28, 2001 and the other on July 7, 2003, in which he confirmed the martyrdom of P. P. Gojdic and Vasil Hopko [31, p. 85,88$]$.

The whole process was completed by ceremonial beatifications. Bishop Pavol Peter Gojdic, OSBM was declared blessed by the Pope John Paul II in St. Peter's Square in Rome on November 4, 2001, together with the Redemptorist priest Metod Dominik Trcka, CSsR [37]. The beatification of Vasil Hopko and Sister Zdenka Schelingova was held on September 14, 2003 in Bratislava - Petrzalka during the third official visit of John Paul II to Slovakia [38].

Not long after both beatifications, the relics of both bishops were transferred to the Cathedral of St. John the Baptist in Presov. The bodily relics of Bishop Pavol Gojdic, OSBM were transferred on November 17, 2001 [39]. The holy liturgy of thanks was celebrated by the Bishop of Presov Mons. Jan Hirka in the Town Sport Hall in Presov. The Apostolic Nuncio in Slovakia, Archbishop Henryk Jozef Nowacki, was also present. The remains were then carried accross the whole town in the presence of many clergy and believers and placed into a sarcophagus in the Chapel of the Holy Cross in the Cathedral of St. John the Baptist [40]. The ceremonial transfer of Bishop Vasil Hopko's relics took place on September 20, 2003. The liturgy was celebrated by the
Prefect of the Congregation for the Oriental Churches, Patriarch Emeritus Ignatius Moses I, Cardinal Daoud from Rome [41].

\section{Bishop Hirka's Recognition}

The Bishop of Presov Mons. Jn Hirka was recognized for his lifetime of work, administering the Greek Catholic Church in Czechoslovakia and Slovakia by both church and state authorities. The Pope Paul VI acknowledged Hirka's activities by granting him the title of 'Honorary Prelate' on March 21, 1978. On December 16, 1998, the Scientific Board of the University of Presov, following the proposal of the Scientific Board of the Faculty of Greek Catholic Theology, awarded Jan Hirka the honorary degree "Doctor honoris causa" [42]. In 1999, on the occasion of Hirka's $75^{\text {th }}$ birthday, the president of the Slovak Republic awarded him the Order of Andrej Hlinka, $1^{\text {st }}$ class and with the Order of Pribina, $2^{\text {nd }}$ class in 2003. The president did so based on the proposal of the Slovak government. In 2006 Hirka became a laureate of Presov Self-governing region and in 2008 he was awarded Jozef Skultety Prize by Matica slovenska [43].

On December 11, 2002, the Pope John Paul II accepted a resignation presented by the Greek Catholic Bishop of Presov Mons. Jnn Hirka, in accordance with canon 210 of CCEO (Code of Canons of the Eastern Churches) and on the same day appointed a new Bishop ThDr. Jan Babjak SJ, PhD. Jan Hirka became Bishop Emeritus. For the short time following the retirement of Jan Hirka, the Presov Eparchy was managed by the general vicar of the eparchy Jan Zavacky, appointed by the Congregation of Consultors on December 16, 2002. In accordance with canon 229 of CCEO he had the same rights and duties as eparchial bishop and he administered the eparchy until ThDr. Jan Babjak SJ, PhD. was consecrated a new residential Bishop of Presov on January 6, 2003 [44].

\section{References}

[1] Though the communist totality ended in 1989, its consequences are still felt today. "Central and Eastern European societies have had a direct experience with ... the atheistic materialism of Communist ideology - with grave socio-political, economic, and especially moral consequences." VALCO, M. - VALCOVA, K.: The Epistemological Challenge of Kierkegaard's Truth is Subjectivity Principle, Communications : Scientific Letters of the University of Zilina, vol. 16, No. 3, 2014, p. 27.

[2] Peace and Mercy under the Protection of Mary (in Slovak), Slovo, vol. 22, 1990, No. 3, p. 1.

[3] The Day of Revival Has Dawned (in Slovak), Slovo, vol. 22, 1990, No. 5, p. 4.

[4] Chronicle of Father Bishop (in Slovak), Slovo, vol. 22, 1990, No. 5, p. 15.

[5] HIRKA, J.: The Demands of the Greek Catholic Church (in Slovak), Slovo, vol. 22, 1990, No. 3, p. 3-4.

[6] After 40 Years Back Home Again (in Slovak)), Slovo, vol. 22, 1990, No. 6, p. 14.

[7] CHOVANEC, J.: Disputes are bad medicine. On matters troubling believers of two Churches in one region (in Slovak), Slobodný piatok, 25 May 1990, p. 4.

[8] HIRKA, J.: Under the Protection of Mary. A Sheperd in Service of the Church (in Slovak). Presov : GTF PU, 2013, p. 208.

[9] LACA, P.: History of the Priest Seminary in Presov (in Slovak), Presov : GTF PU, 2009, p. 55. 
[10] MAREK, P., BUREHA, V.: The Orthodox in Czechoslovakia in 1918 - 1953 (in Czech), Brno : CDK, 2008, p. 421.

[11] TEAM OF AUTHORS: Register of Monuments in Slovakia, part 2, $K$ - P (in Slovak), Bratislava : Obzor, 1968, p. 558.

[12] STURAK, P.: Historical Outline of Theological Education in Greek Catholic Church in Slovakia (in Slovak), in J. Coranič (ed.): The Church in the History of Christianity in Slovakia (in Slovak), Presov: GTF PU, 2014, p. 17.

[13] DANCAK, F.: The Faculty of Greek Catholic Theology opened in Presov (in Slovak), Slovo, vol. 23, 1991, No. 1, p. 9.

[14] KORMANIK, V.: A Brief Look at the History of Seminary (in Slovak), in 125. Academia teologica: "Heritage and the future", Presov : Petra, No., 2006, p. 21.

[15] POLACEK, V.: Mission of the Faculty (in Slovak), Univerzita Pavla Jozefa Safarika v Kosiciach 1990 - 1991. Study programme, general section, Faculty of Greek Catholic Theology, Kosice : 1990, p. 1.

[16] Report of Higher Education Institution (in Slovak), data as of 31.10.1990, Archive of the Study deprtment of the Greek Catholic Theological Faculty, University of Presov in Presov.

[17] Report of Higher Education Institution (in Slovak), data as of 31.10.1991), Archive of the Study department of the Greek Catholic Theological Faculty, University of Presov in Presov.

[18] Report of Higher Education Institution, data as of 31.10 .1992 (in Slovak), Archive of the Study department of the Greek Catholic Theological Faculty, University of Presov in Presov).

[19] LIPTAK, R.: 88 years of Catholic Theology Study in Presov (in Slovak), History of the Greek Catholic Education in Slovakia II, Presov : 2009, p. 112.

[20] POLACEK, V.: Introduction (in Slovak), Study programme, Faculty of Greek Catholic Theology P. J. Safarika 1993-1994, Kosice : UPJS, 1993, p. 3.

[21] JANHUBA, F.: Introduction (in Slovak), Study programme, Faculty of Greek Catholic Theology P. J. Safarika 1996-1997, Presov, 1996, p. 6.

[22] SIMKO, M.: History of the Greek Catholic Priest Seminary of Blessed Pavol Peter Gojdic in Presov (in Slovak), History of the Greek Catholic Education in Slovakia II, Presov, 2009, p. 158.

[23] MATLOVIC, R.: 15 years of the Presov University in Presov), Presovska univerzita v Presove, Presov : Vydavatelstvo PU, 2012 , p. 9.

124] Amendment No. 1 to the Statute of the Faculty of Greek Catholic Theology, University of Presov in Presov (in Slovak), Resolution No. 33 of Academic Senate of the Faculty of Greek Catholic Theology, University of Presov in Presov); http://www.unipo.sk/ public/media/1502/Vypisy\%20uzneseni\%20 AS\%20GTF\%202003-2007.pdf.

[25] RUSNAK, A.: In Episcopal Service. 18th Anniversary of Episcopal Consecration of Mons. Jan Hirka (in Slovak), Slovo, vol. 40, No. 7, 2008, p. 8.

[26] HRIVNAK, S.: Greek Catholic Eparchy in Presov 1323 - 1821 - 1950 (in Slovak), State District Archive, Presov, 1968, No. 2.

[27] CORANIC, J.: Archive of the Greek Catholic Eparchy in Presov (in Slovak), Archiva ecclesiastica 5: biuletyn stowarzyszenia archiwistow koscielnych, Katowice : Ksiegarnia sw. Jacka, 2012, pp. 10-11.

[28] Bishop Milan Chautur, C.SS.R. Bishop of Kosice, in http://www.catholic-hierarchy.org/bishop/ bchautur.html.

[29] HOSPODAR, M.: Vladyka Milan Chautur CSsR, the first Greek Catholic Eparch from Kosice (in Slovak), Slovo, vol. 40, No. 5-6, 2008, p. 14.

[30] PETRIK, L.: 10th Anniversary of the Papal Visit to Presov (in Slovak), Greek Catholic Calendar 2005, Kosice : Byzant s.r.o., 2004, p. 32-34.

[31] KREHLIK, J.: History and chronology of the beatification process of the blessed bishop - martyr ThDr. Vasil Hopko, Midilsky Titular Bishop and Auxiliary Bishop of the Bishop of Presov (in Slovak), in V. Bohac (ed.): The Reflection of unity in the work and life of the blessed bishop Vasil Hopko (1904-1976) in the context of the European integration process (in Slovak), Presov : GTF PU, 2010, pp. 77-78.

[32] STURAK, P.: Pavol Peter Gojdic OSBM, the Greek Catholic Bishop of Presov (1926 - 1960) - (in Slovak), Presov : GTF PU, 2013, p. 92.

[33] Address of John Paul II to the Greek Catholic believers in Presov on 2 July 1995 (in Slovak), Greek Catholic Calendar 1996), Michalovce : Byzant, 1995, p. 36.

[34] KOSIAR, J., LABO, S., VRAGAS, S.: Apostle of the Nations of the 20th Century (in Slovak), Second visit of John Paul II to Slovakia, Trnava : Dobra kniha, 1995, p. 137.

[35] STURAK, P.: The Beatification Process of Bishop P. P. Gojdic (in Slovak), in R. Letz (ed.): They were Three. 50 years Since the Political Trial with Slovak Catholic Bishops (in Slovak), Bratislava, 2001, p 137.

[36] KREHLIK, J.: The Gojdic Case: About the Process of Beatification of Vladyka Pavol Peter Gojdic (in Slovak), Slovo, vol. 38, No. 23, 12. 11. 2006, pp. 8-9.

[37] Pavol Peter Gojdic (in Slovak), A commemoration published for the event of his beatification on November 4, 2001, Presov, 2001. 
[38] Blessed Bishop Vasil Hopko, Biography, Prayers, thoughts (in Slovak), Published by the Greek Catholic Eparchy in Presov on occasion of beatification of Vasil Hopko on 14 September 2003 in Bratislava, Presov, 2003.

[39] PRIBULA, M.: Ceremonial Transfer of Relics (in Slovak), Slovo, vol. 33, Presov, January 2002, p. 7.

[40] KOSUTOVA, A.: The Relics of Bishop Gojdic will be Transferred and Laid in the Chapel on Saturday (in Slovak), Korzar, 14, 11. 2001, http://korzar.sme.sk/c/4677802/v-sobotu-slavnostne-prenesu-relikvie-biskupa-gojdica-a-ulozenia-ich-do-kaplnky.html.

[41] PETRIK, L: History of the Cathedral of St. John the Baptist and the Bishop's Residence in Presov (in Slovak), Presov : Petra, 2007, p. 98.

[42] STURAK, P., PALA, G., CORANIC, J. (eds.): Messengers of Faith, Wisdom and Knowledge, Presov : GTF PU, 2010, pp. 23-35.

[43] PETRO, M., STURAK, P.: The Greek Catholic Church in Slovakia, part 1 (in Slovak), Heritage of St. Cyril and Methodius, Presov : Petra, 2012, p. 164

[44] Interim Administrator to Presov Eparchy (in Slovak), in http://grkatpo.sk/?spravy\&id=265. 